\title{
Antioxidant Activity of Hawthorn Fruit in vitro
}

\author{
Chunmei Li, Woong Han, and Myeong-Hyeon Wang* \\ School of Biotechnology, Kangwon National University, Chuncheon, Kangwon-Do 200-701, South Korea
}

Received April 14, 2009; Accepted February 11, 2010

\begin{abstract}
The antioxidant activity of hawthorn fruit (Crataegus pinnatifida Bunge var. typica Schneider) extracts was investigated by several in vitro antioxidants properties, including DPPH free radical scavenging activity, total phenolic and flavonoid contents, hydroxyl radical scavenging activity, reducing power activity, iron-chelating capacity and nitrite scavenging activity. Among the extracts in this study, the $\mathbf{7 0} \%$ EtOH extract showed higher antioxidant activity than the others. $\mathrm{The}^{\mathrm{IC}} \mathrm{C}_{\mathbf{5 0}}$ value of DPPH free radical scavenging activity was $99.26 \mu \mathrm{g} / \mathrm{mL}$. Furthermore, the $70 \%$ EtOH extract also showed significantly high total phenolic and flavonoids contents and reducing power activity. However, the MeOH extract exhibited stronger effects on hydroxyl radical scavenging activity, iron-chelating capacity and nitrite scavenging activity. All the results implicated that, the hawthorn fruit may has the available potential to be utilize as a potential source of natural antioxidant.
\end{abstract}

Key words: antioxidant activity, hawthorn fruit, reactive oxygen species

Reactive oxygen species and reactive nitrogen species such as $\cdot \mathrm{O}_{2}^{-}$, $\cdot \mathrm{OH}$ (hydroxyl radicals), $\mathrm{H}_{2} \mathrm{O}_{2}$ and $\mathrm{NO}$, constantly produced by ultraviolet light and chemic pollution, result in the oxidative stress. This oxidative stress can react rapidly with other substances including DNA, membrane lipids and proteins [Fang et al., 2002]. Many diseases such as cardiovascular disease, diabetes mellitus, gastric ulcers, cancer, arthritis, Alzheimer's disease, and Parkinson's disease are related to the oxidative stress [Butterfield et al., 2002]. Antioxidant like vitamin $\mathrm{C}$, vitamin $\mathrm{E}$, carotenes, phenolic acids, phytate and phytoestrogens may terminate the attack of reactive species and reduce the risk of correlative diseases [Pryor et al., 1991; Larson. et al., 1995; Jacob, 1996].

Hawthorn fruit is the red berries of the Crataegus species. As a medicinal plant, the hawthorn fruit is considered to be generally safe and well-tolerated in the treatment of cardiovascular diseases, angina pectoris of coronary heart disease [Pryor et al., 1991; Rigelsky et al., 2002]. The extract is clinically effective in reducing blood pressure and total plasma cholesterol [Hanack et al., 1983], and can be treated for indigestion and retention of food due to improper diet or excessive intake of greasy food or meat. It was suggested that the antioxidants may play an important role in understanding the mechanisms of protective effects of hawthorn extract [Von Eiff et al., 1994; Zhang et al.,

*Corresponding author

Phone: +82-33-250-6486; Fax: +82-33-241-6480

E-mail: mhwang@kangwon.ac.kr

doi:10.3839/jabc.2010.002
2001]. Recently, the phenolic profiles and antioxidative effects of cell suspensions, fresh fruits and medicinal dried parts from hawthorn also has been investigated [Froehlicher et al., 2009].

In present investigation, we designed to evaluate the antioxidant activities of hawthorn fruit by several in vitro assays, including DPPH free radical scavenging activity, hydroxyl radical scavenging activity, the total phenolic and flavonoid contents, reducing power activity and iron-chelating capacity. Furthermore, the potential nitrite scavenging activity of the extracts has also been identified.

\section{Materials and Methods}

Sample preparation. The hawthorn fruit was the bright red berries of the Crataegus pinnatifida Bunge var. typica Schneider. The fruits were collected from native trees in Chuncheon, South Korea, in autumn, 2008. Freshly-harvested whole hawthorn fruits were shade-dried and then finely powdered. Powder $(50 \mathrm{~g})$ was extracted twice with $1 \mathrm{~L}$ of different solvents, water, boiling water, $\mathrm{MeOH}, 70 \% \mathrm{MeOH}, \mathrm{EtOH}, 70 \% \mathrm{EtOH}$ and chloroform. The extract was filtered (100-mm; Whatman, Maidstone, UK), and the filtrate was evaporated under reduced pressure using a vacuum rotary evaporator (CCA-1110; Eyela, Tokyo, Japan). The dried extracts were stored at $-20^{\circ} \mathrm{C}$ until further analysis.

DPPH free radical scavenging activity. The free radical scavenging activity of hawthorn fruit extracts was evaluated by the method described by Zhang et al. [2009] with several modifications. Briefly, a $50 \mu \mathrm{L}$ of $0.1 \mathrm{mM}$ DPPH solution was added to varying concentrations of each extract, vortex-mixed 
and incubated at room temperature for $30 \mathrm{~min}$. The absorbance was measured at $515 \mathrm{~nm}$ against the blank. The scavenging ratio by each sample extract was calculated using the following equation:

\section{DPPH scavenging activity $(\%)=\left[\mathrm{A}_{0}-\left(\mathrm{A}_{1}-\mathrm{A}_{\mathrm{s}}\right)\right] / \mathrm{A}_{0} \times 100$}

Where $A_{0}, A_{1}$, and $A_{s}$ were the absorbance of the control, extracts of sample and blank, respectively.

The scavenging ratio by pure compound was calculated using the following equation:

\section{DPPH scavenging activity $(\%)=\left(\mathrm{A}_{0}-\mathrm{A}_{1}\right) / \mathrm{A}_{0} \times 100$}

Where $A_{0}$ and $A_{1}$ were the absorbance of the control and antioxidant compound, respectively.

Inhibition $\left(\mathrm{IC}_{50}\right)$ was calculated from the graph of $\mathrm{DPPH}$ scavenging activity against extract concentration.

Determination of total phenolic and flavonoid contents. $0.1 \mathrm{~mL}$ of $1 \mathrm{mg} / \mathrm{mL}$ each extract was mixed with $0.5 \mathrm{~mL}$ of $0.1 \mathrm{~N}$ Folin-Ciocalteu reagent and $0.4 \mathrm{~mL}$ of $7.5 \%$ sodium carbonate solution. After incubated at room temperature for 30 min, the absorbance was measured at $760 \mathrm{~nm}$ against the blank. The total phenolic content was determined with respect to the standard curve of tannic acid, and was expressed as tannic acid equivalent [Jung et al., 2008].

The total flavonoid content was evaluated by a colorimetric method described by Liu et al. [2002], with slight modification. A mixture of $0.25 \mathrm{~mL}$ each extract, $1.25 \mathrm{~mL}$ distilled water, and $75 \mu \mathrm{L}$ of $5 \% \mathrm{NaNO}_{2}$ solutions was incubated at room temperature for $6 \mathrm{~min}$, then $150 \mu \mathrm{L}$ of $10 \% \mathrm{AlCl}_{3} \cdot 6 \mathrm{H}_{2} \mathrm{O}$ solution was added to the mixture and incubated for further $6 \mathrm{~min}$. The reaction was terminated by adding $0.5 \mathrm{~mL}$ of $1 \mathrm{M}$ sodium hydroxide. The absorbance was measured at $510 \mathrm{~nm}$ against the blank. The total flavonoid content was quantified with respect to the standard curve of catechin, and expressed as catechin equivalent.

Measurement of nitrite scavenging activity. Since nitrite ions in the acidic environment of human body can induce mutagenic and cell-damaging reactions [Yin et al., 2007], we simulated different $\mathrm{pH}$ environment in this study to evaluate the nitrite scavenging activity of hawthorn fruit. Set $\mathrm{pH} 1.2$ was obtained by $0.1 \mathrm{~N} \mathrm{HCl}$, and $\mathrm{pH} 4.2$ or $\mathrm{pH} 6.0$ by $0.2 \mathrm{M}$ citric acid buffer. A mixture of $1 \mathrm{~mL}$ of $1 \mathrm{mM}$ nitrite solution, $1 \mathrm{~mL}$ sample solution and $8 \mathrm{~mL}$ different buffer was incubated at $37^{\circ} \mathrm{C}$ in water bath for $1 \mathrm{~h}$, and $1 \mathrm{~mL}$ was taken to mix with $2 \mathrm{~mL}$ of $2 \%$ acetic acid and $0.4 \mathrm{~mL}$ Griess reagent $(1: 1$, solution of $1 \%$ sulfanilic acid in $30 \%$ acetic acid and $1 \%$ of naphthylamine in $30 \%$ acetic acid). It was vortex-mixed and kept at room temperature for $15 \mathrm{~min}$. Then, the absorbance was measured at $520 \mathrm{~nm}$. The scavenging ratio by pure compound was calculated using the following equation:
Nitrite scavenging effect $(\%)=\left[\mathrm{A}_{0}-\left(\mathrm{A}_{1}-\mathrm{A}_{\mathrm{s}}\right)\right] / \mathrm{A}_{0} \times 100$

Where $A_{0}, A_{1}$, and $A_{s}$ were the absorbance of the control, extracts of sample and the sample blank without Griess reagent, respectively.

-OH scavenging activity. $\cdot \mathrm{OH}$ scavenging activity of hawthorn fruit extracts was based on 2-deoxyribose oxidation assay [Chung et al., 1998]. A reactive mixture containing $0.2 \mathrm{~mL}$ of $10 \mathrm{mM} \mathrm{FeSO} \cdot 7 \mathrm{H}_{2} \mathrm{O}, 0.2 \mathrm{~mL}$ of $10 \mathrm{mM}$ ethylenediaminetetraacetic acid, $0.2 \mathrm{~mL}$ of $10 \mathrm{mM}$ 2-deoxyribose solution, and $0.2 \mathrm{~mL}$ samples solution was mixed with $1 \mathrm{~mL}$ sodium phosphate buffer $(\mathrm{pH} 7.4,0.1 \mathrm{M})$ and $0.2 \mathrm{~mL}$ of $10 \mathrm{mM}$ of $\mathrm{H}_{2} \mathrm{O}_{2}$. Then, the mixture was incubated at $37^{\circ} \mathrm{C}$ for $4 \mathrm{~h}$. After incubation, $1 \mathrm{~mL}$ of $2.8 \%$ trichloroacetic acid and $1.0 \% 2-$ thiobarbituric acid were added to the reaction mixture. The resultant mixture was incubated in boiled water bath for $10 \mathrm{~min}$. After cooled, the absorbance was measured at $532 \mathrm{~nm}$. $\alpha$ Tocopherol was used as the positive control. The scavenging activity was calculated using the following equation:

-OH scavenging activity $(\%)=\left(\mathrm{A}_{0}-\mathrm{A}_{1}\right) / \mathrm{A}_{0} \times 100$

Where $A_{0}$ was the absorbance of the control and $A_{1}$ was the absorbance in the presence of the sample.

Iron-chelating capacity. The iron-chelating capacity of hawthorn fruit extracts was measured by the method used by Hsu et al. [2003]. The solution of each extract was prepared to the concentrations of $10-1000 \mu \mathrm{g} / \mathrm{mL} .1 \mathrm{~mL}$ aliquot was mixed with $1 \mathrm{~mL}$ of methanol, $0.1 \mathrm{~mL}$ of $2 \mathrm{mM} \mathrm{FeCl}_{2} \cdot 4 \mathrm{H}_{2} \mathrm{O}$, and 0.2 $\mathrm{mL}$ of $5 \mathrm{mM}$ ferrozine. After incubated at room temperature for $10 \mathrm{~min}$, the mixture was measured at $562 \mathrm{~nm}$. Ethylenediaminetetraacetic acid was used as positive control with the same concentrations. All spectrophotometric measurements were carried out three times. The percentage of inhibition of ferrozine- $\mathrm{Fe}^{2+}$ complex formation is given by this formula:

$$
\text { Inhibition }(\%)=\left(\mathrm{A}_{0}-\mathrm{A}_{1}\right) / \mathrm{A}_{0} \times 100
$$

Where $\mathrm{A}_{0}$ was the absorbance of the control and $\mathrm{A}_{1}$ was the absorbance in the presence of the sample.

Reducing powers activity. The reducing power activity assay was described by Rowena et al. [2009]. $1 \mathrm{~mL}$ of the extracts or control solution with concentration $0-1000 \mu \mathrm{g} / \mathrm{mL}$ was mixed with sodium phosphate buffer $(0.2 \mathrm{mM}, \mathrm{pH} 6.6)$ and $1 \mathrm{~mL}$ of $1 \%$ potassium ferricyanide $\left(\mathrm{K}_{3} \mathrm{Fe}(\mathrm{CN})_{6}\right)$. The mixture was incubated at $50^{\circ} \mathrm{C}$ for $20 \mathrm{~min}$. The reaction was terminated by added $1 \mathrm{~mL}$ of $10 \%$ trichloroacetic acid solution. Then, the mixture was centrifuged at $3000 \mathrm{rpm}$ for $10 \mathrm{~min}$. $1 \mathrm{~mL}$ upper layer solution was added to the solution of $1 \mathrm{~mL}$ of distilled water and $0.2 \mathrm{~mL}$ of $0.1 \% \mathrm{FeCl}_{3}$ solution. The absorbance was measured at $700 \mathrm{~nm}$. The increased absorbance indicated increased reducing power activity. 
Statistical analysis. All experiments were conducted in independent triplicate and data was expressed as mean \pm standard deviation.

\section{Result and Discussion}

Hawthorn fruit extraction yield by different solvents. The yields of different extracts were exhibited as percent (\%) of dried extracts/fresh fruit $(50 \mathrm{~g})$. As Table 1 showed, the yields were ranked as followed order: boiling water extract (31.22\%, 15.61 g), water extract $(30.36 \%, 15.18 \mathrm{~g}), 70 \% \mathrm{MeOH}$ extract $(28.60 \%, 14.30 \mathrm{~g}), 70 \% \mathrm{EtOH}$ extract $(28.46 \%, 14.23 \mathrm{~g})$, $\mathrm{MeOH}$ extract $(24.86 \%, 12.43 \mathrm{~g}), \mathrm{EtOH}$ extract $(21.72 \%, 10.86$ $\mathrm{g})$, and chloroform extract $(2.28 \%, 1.14 \mathrm{~g})$.

DPPH radical scavenging activity. Being a free radical donor, DPPH is expected to accept an electron or hydrogen to become a stable diamagnetic molecule. Based on its changeable color, DPPH is used widely to evaluate the antioxidant activity of various compounds [Hu et al., 2000]. The scavenging activity of the extracts from hawthorn fruit against DPPH free radical has been evaluated at concentration $10-200 \mu \mathrm{g} / \mathrm{mL}$ and the result was shown in Table 1. 70\% EtOH extract and 70\% $\mathrm{MeOH}$ extract showed higher DPPH scavenging activity than the other extracts. Compared to positive control $\alpha$-tocopherol, the results

Table 1. The yields and DPPH scavenging activity of different extracts from Hawthorn fruit

\begin{tabular}{lcc}
\hline \hline Extracts & Yield $(\%)$ & $\begin{array}{c}\text { DPPH scavenging } \\
\text { activity } \\
\left(\mathrm{IC}_{50}{ }^{\mathrm{a}}: \mu \mathrm{g} / \mathrm{mL}\right)\end{array}$ \\
\hline Water & 30.36 & $190.53 \pm 0.98$ \\
Boiling water & 28.60 & $157.77 \pm 2.58$ \\
$\mathrm{MeOH}$ & 24.86 & $123.70 \pm 0.88$ \\
$70 \% \mathrm{MeOH}$ & 31.22 & $103.58 \pm 0.19$ \\
EtOH & 21.72 & $150.77 \pm 2.50$ \\
$70 \%$ EtOH & 28.46 & $99.26 \pm 1.13$ \\
Chloroform & 2.28 & $572.31 \pm 3.40$ \\
$\alpha$-Tocopherol & - & $7.60 \pm 0.59$ \\
\hline
\end{tabular}

${ }^{\mathrm{a}} \mathrm{IC}_{50}$ : the effective concentration at which DPPH radicals were scavenged by $50 \%$.

Table 2. Total phenolic and flavonoid contents of different extracts from Hawthorn fruit

\begin{tabular}{lcc}
\hline \hline Extracts & $\begin{array}{r}\text { Total phenolic content } \\
\left.\text { tannic }^{\mathrm{a}} \mathrm{mg} / \mathrm{g}\right)\end{array}$ & $\begin{array}{c}\text { Flavonoid content } \\
\left.\text { (catechin }^{\mathrm{b}} \mathrm{mg} / \mathrm{g}\right)\end{array}$ \\
\hline Water & $36.63 \pm 1.05$ & $10.14 \pm 0.49$ \\
Boiling water & $44.24 \pm 0.75$ & $12.94 \pm 0.56$ \\
MeOH & $38.07 \pm 1.22$ & $18.31 \pm 0.49$ \\
$70 \% \mathrm{MeOH}$ & $49.02 \pm 1.08$ & $18.63 \pm 0.37$ \\
EtOH & $34.69 \pm 0.66$ & $14.12 \pm 0.49$ \\
$70 \%$ EtOH & $53.75 \pm 0.32$ & $20.35 \pm 0.65$ \\
Chloroform & $12.95 \pm 0.18$ & - \\
\hline
\end{tabular}

${ }^{\text {aTotal }}$ phenolic content is expressed as tannic equivalent $\mathrm{mg} / \mathrm{g}$.

${ }^{\mathrm{b}}$ Total flavonoid content is expressed as catechin equivalent $\mathrm{mg} / \mathrm{g}$. suggested that the extracts (except the chloroform extract) showed fairish scavenging activity. It may be due to some phenolic compounds present in hawthorn fruit [Froehlicher et al., 2009].

Total phenolic and flavonoid contents. Phenolic compounds are widely distributed in plants, which are significantly effective in free radical scavenging and antioxidant activity [Siriwardhana et al., 2003]. As polyphenolic antioxidant, flavonoid is naturally present in vegetables, fruits, and some beverages [Hertog et al., 1993]. Therefore, the total phenolic and flavonoid contents assays are the usual method for testing the antioxidant activity. Different from the report described by Froehlicher et al. [2009] which showed scarcely less flavonoid in dried hawthorn fruit, most of the extracts in this study showed a certain extent of flavonoid (Table 2). $70 \%$ EtOH extract exhibited higher phenolic and flavonoid contents than any other extracts; the chloroform extract showed lowest phenolic and flavonoid contents. Connect with DPPH free radical scavenging activity, it was confirmed that the phenolic compounds have eximious effect on free radical scavenging and antioxidant activity.

Nitrite scavenging activity. At different $\mathrm{pHs}$, the extracts had different activity on nitrite scavenging effects (Fig. 1), pH 1.2> $\mathrm{pH}$ 4.2>pH 6.0. Furthermore, different extracts showed different activities. At each $\mathrm{pH}$, the $\mathrm{MeOH}, 70 \% \mathrm{MeOH}, \mathrm{EtOH}$, and $70 \%$ EtOH extracts showed higher effect than water, boiling water, and chloroform extracts. At $\mathrm{pH} 4.2$ and $\mathrm{pH} 6.0$, the water, boiling water, and chloroform extracts exhibited slight activity. Since the nitrite is toxic, the excess amounts of nitrite in human body over time may induce the oxidization of hemoglobin and lead to methemoglobinemia [Jeon et al., 2002]. The nitrite scavenging activity of hawthorn fruit suggested that, hawthorn fruit might have potential activity on human body protecting.

-OH scavenging activity. Based on deoxyribose oxidation assay, the activity increased depending on the concentration (Fig. 2). Compared to the positive control $\alpha$-Tocopherol at concentration $100 \mu \mathrm{g} / \mathrm{mL}$, part of hawthorn fruit extracts such as

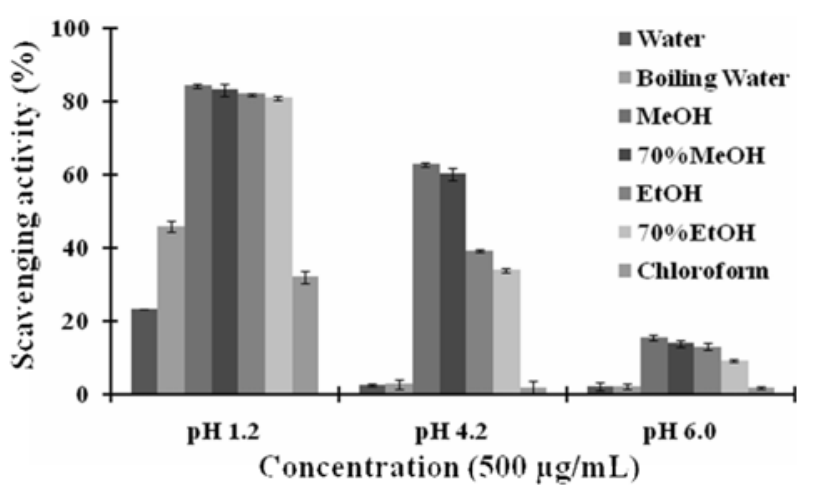

Fig. 1. Nitrite scavenging activity of different extracts from Hawthorn fruit. Different environments respectively were $\mathrm{pH} 1.2, \mathrm{pH}$ 4.2 and $\mathrm{pH} 6.0$. 


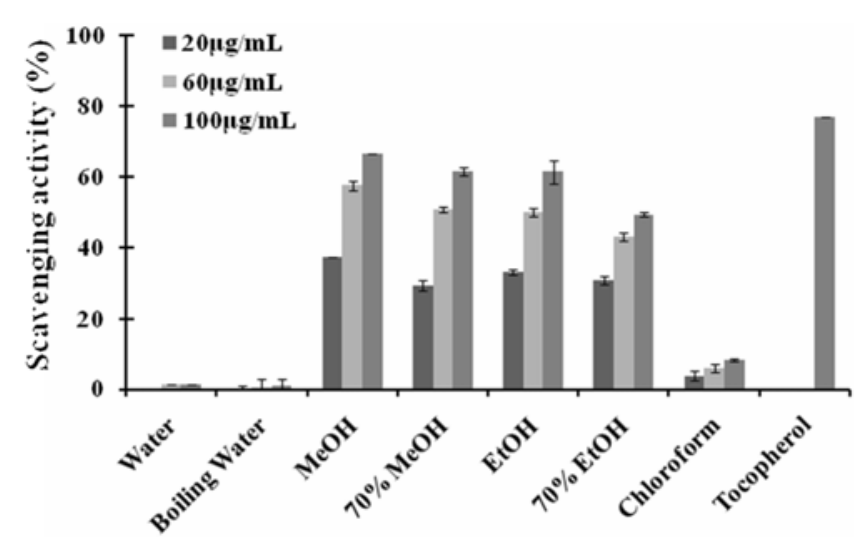

Fig. 2. $\cdot \mathrm{OH}$ scavenging activity of different extracts from Hawthorn fruit. The concentrations of testing sample were $20 \mu \mathrm{g} / \mathrm{mL}$, $60 \mu \mathrm{g} / \mathrm{mL}$ and $100 \mu \mathrm{g} / \mathrm{mL}$. $100 \mu \mathrm{g} / \mathrm{mL} \alpha$-Tocopherol was used as the positive control.

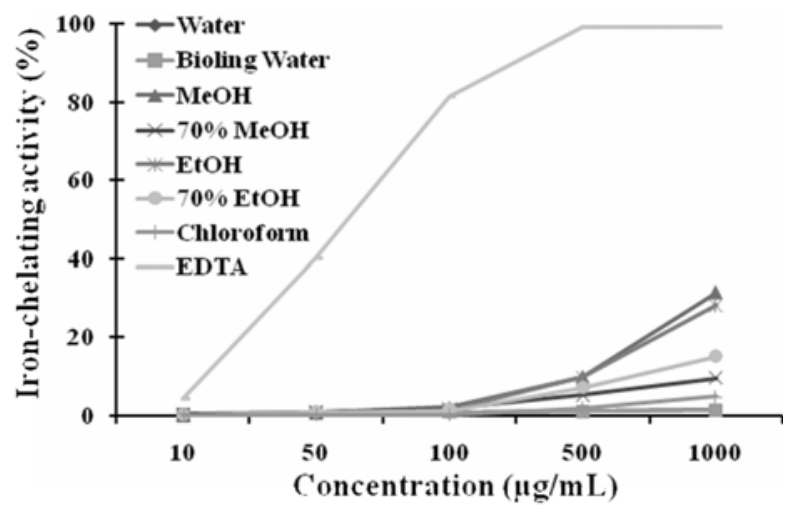

Fig. 3. Iron-chelating capacity of different extracts from Hawthorn fruit.

$\mathrm{MeOH}, 70 \% \mathrm{MeOH}$, EtOH, and 70\% EtOH showed considerable hydroxyl radical scavenging effect, while others showed slight sign between different concentrations. Since $\bullet \mathrm{OH}$ is one of the reactive free radicals and may do harm to DNA, membrane lipids and proteins [Jung et al., 2008], the hawthorn fruit may have protective effect on against the damage to DNA and cell.

Iron-chelating capacity. It was reported that the antioxidants as chelators of metal ions played an important role in inhibiting the lipid oxidation or metal complexes formation [Gimenez et al., 2009; Hsu et al., 2003]. The result of iron-chelating capacity of the extracts was shown in Fig. 3. EDTA as the positive control exhibited high chelated activity, and the metal ion was completely chelated at the concentration of $500 \mu \mathrm{g} / \mathrm{mL}$. The ability of the extracts was ranked as following order: $\mathrm{MeOH}>$ $\mathrm{EtOH}>70 \% \quad \mathrm{EtOH}>70 \% \quad \mathrm{MeOH}>$ chloroform $>$ boiling water $>$ water. However, the activity of all extracts was not significantly different. The iron-chelating capacity may be due to some particular phenolics compounds that are skimpy in hawthorn fruit.

Reducing powers activity. It was reported a positive correlation between antioxidant activity and reducing power

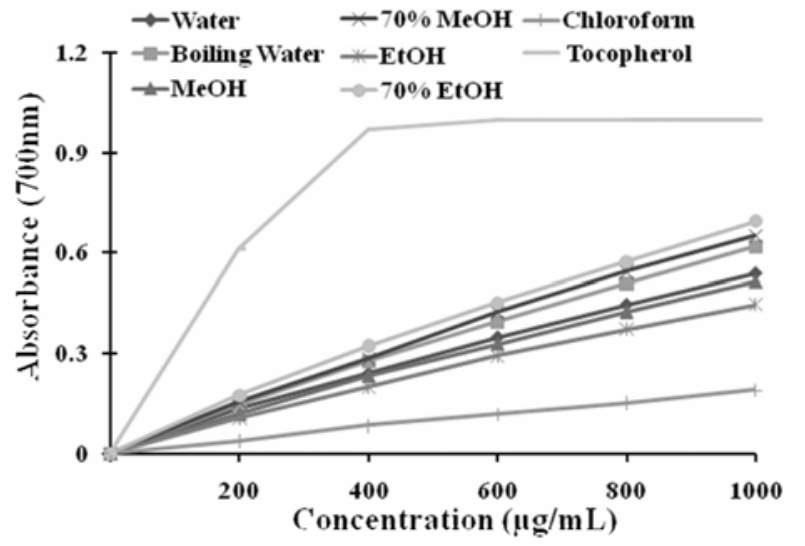

Fig. 4. Reducing power activity of the different extracts from hawthorn fruit. $\alpha$-Tocopherol was used as a positive control.

[Duh et al., 1997; Yuan et al., 2005]. As shown in Fig. 4, all extracts showed reducing power activities in a dose-dependent manner. The reducing power of hawthorn fruit extracts was ranked as following descending order: $70 \% \mathrm{EtOH}>70 \% \mathrm{MeOH}$ $>$ boiling water $>$ water $>\mathrm{MeOH}>$ EtOH $>$ chloroform. Compared to $\alpha$-Tocopherol at the same concentrations, the extracts exhibit moderate reducing powers. It suggested hawthorn fruit has potential antioxidant activity.

In conclusion, the extracts of hawthorn fruit exhibited moderate antioxidant activities by several in vitro assays. Though, all the results were lower than the standards, they were sufficient for suggesting that hawthorn fruit might be a potential source of natural antioxidant. It was reported that in hawthorn fruit, there were many pure compounds, such as isoquercitrin, epicatechin, quercetin, rutin and protocatechuic acid [Zhang et al., 2001]. However, it was not sufficiently comprehensive. Therefore, there's still adequacy space for our further research.

\section{References}

Buttereld DA, Castenga A, Pocernich CB, Drake J, Scapagnini G, and Calabrese V (2002) Nutritional approaches to combat oxidative stress in Alzheimer's diseases. J Nutr Biochem 13, 444-461.

Chung SK and Osawa T (1998) Hydroxy radical scavengers from white mustard (Sinapis alba). Food Sci Biotechnol 7, 209-213

Duh PD and Yen GC (1997) Antioxidative activity of three herbal water extracts. Food Chem 60, 639-645.

Fang YZ, Yang S, and Wu GY (2002) Free radicals, antioxidants and nutrition. Nutrition 18, 872-879.

Froehlicher T, Hennebelle T, Françoise MN, Cleenewerck P, Hilbert JL, Trotin F, and Grec S (2009) Phenolic profiles and antioxidative effects of hawthorn cell suspensions, fresh fruits, and medicinal dried parts. Food Chem 115, 897-903.

Giménez B, Alemán A, Montero P, Hanack T and Bruckel MH (1983) The treatment of mild stable forms of angina pectoris using Crategutt novo. Therapiewoche 33, 4331-4333. 
Hertog MGL, Feskens EJ M, Hollman PCH, Katan MB, and Kromhout D (1993) Dietary antioxidant flavonoids and risk of coronary heart disease: The Zutphen elderly study. Lancet $\mathbf{3 4 2}$, 1007-1011.

Hu C and Kitts DD (2000) Studies on the antioxidant activity of Echinacea root extract. J Agric Food Chem 48, 1466-1472.

Hsu CL, Chen W, Weng YM, and Tseng CY (2003) Chemical composition, physical properties, and antioxidant activities of yam flours as affected by different drying methods. Food Chem 83, 85-92.

Jacob R (1996) Three eras of vitamin C discovery. Subcell Biochem 25, 1-16.

Jeon TW, Jo CH, Kim KH, and Byun MW (2002) Inhibitory effect on tyrosinase and xanthine oxidase, and nitrite scavenging activities of Schizandrae Fructue extract by gamma irradiation. J Kor Food Pres 9, 369-374.

Jung MJ, Heo SI, and Wang MH (2008) Free radical scavenging and total phenolic contents from methanolic extracts of Ulmus davidiana. Food Chem 108, 482-487.

Larson RA (1995) Plant defenses against oxidative stress. Arch Insect Biochem Physiol 29, 175-186.

Liu M, Li XQ, Weber C, Lee CY, Brown J, and Liu RH (2002) Antioxidant and antiproliferative activities of raspberries. $J$ Agric Food Chem 50, 2926-2930.

Mee JJ, Heo SI, and Wang MH (2008) Antioxidant activity of different parts of Synurus deltoids Nakai extracts in vitro. Food
Sci Biotechnol 17, 1156-1159.

Pryor WA (1991) The antioxidant nutrients and disease preventionWhat do we know and what do we need to find out. Am J Clin Nutr 53, S391-S393.

Rigelsky JM and Sweet BV (2002) Hawthorn: pharmacology and therapeutic uses. Am J Health Syst Pharm 59, 417-422.

Rumbaoa RGO, Cornago DF, and Geronimo IM (2009) Phenolic content and antioxidant capacity of Philippine sweet potato (Ipomoea batatas) varieties. Food Chem 113, 1133-1138.

Von Eiff M (1994) Hawthorn/Passionower extract and improvement in physical capacity of patients with dyspnoea Class II of the NYHM functional classication. Acta Ther 20, 47-66.

Yuan YV, Bone DE, and Carrington MF (2005) Antioxidant activity of dulse (Palmaria palmata) extract evaluated in vitro. Food Chem 91, 485-494.

Yin J, Kwon GJ, and Wang MH (2007) The antioxidant and cytotoxic activities of Sonchus oleraceus L. extracts. Nutr Res Pract 1, 189-194.

Zhang ZS, Chang Q, and Zhu M (2001) Characterization of antioxidants present in hawthorn fruits. $J$ Nutr Biochem 12, 144-152.

Zhang ZJ, Liao LP, and Moore J (2009) Antioxidant phenolic compounds from walnut kernels (Juglans regia L.). Food Chem 113, 160-165. 